\title{
Science-Based Thematic Cultural Art Learning in Primary School (2013 Curriculum)
}

\author{
Warih Handayaningrum, I Nyoman Lodra, Susanah, Bambang Sugito \\ Pendidikan Sendratasik Universitas Negeri Surabaya \\ Kampus Lidah Wetan Surabaya, Indonesia \\ ${ }^{\square}$ E-mail: warihsendratasik@yahoo.com
}

Received: Februari 28, 2016. Revised: Maret 23, 2016. Accepted: June 24, 2016

\begin{abstract}
This study is aimed at discussing the development result of thematic cultural art subject's learning material based on science for primary school (2013 curriculum). This study is expected to inspire teacher to develop learning material that may explore artworks exist in our living environment (based on the context of children's environment). This study applies steps in developmental research collaboration by Borg \& Gall (1989) and Puslitjaknov (2008) to create the product. The development stages comprise observation in several primary schools in Surabaya, Gresik, and Sidoarjo that has implemented 2013 curriculum that is followed up by stages of development. Furthermore, prototype of cultural and art thematic learning material development results are verified by learning material experts, material expert, primary school teacher, and revised afterwards. The result of this research development is a set of teacher and student books. Sciencebased cultural art here means cultural art learning as the main medium to introduce local culture products (music, drawing, dance, and drama) by integrating mathematics, sciences, Bahasa Indonesia, and local language subjects. Cultural art products in the form of dance, music, drawing, dramas) will help children to understand a simple mathematical concept, such as: two-dimensional figure, geometry, comparing or estimating longer-shorter, smaller-bigger, or more-less.
\end{abstract}

Keywords: cultural art; thematic; scientific-based learning

How to Cite: Handayaningrum, W., Lodra, I. N., Susanah \& Sugito, B. (2016). Science-Based Thematic Cultural Art Learning in Primary School (2013 Curriculum). Harmonia: Journal of Arts Research And Education, 16(1), 14-23. doi:http:// dx.doi.org/10.15294/harmonia.v16i1.6766

\section{INTRODUCTION}

In Indonesian 2013 Curriculum, the expected output is known as future competence. The future competence itself is the ability to communicate, to think clearly and critically, to consider the moral perspective of a certain problem, to become a responsible citizen, to have readiness to work, to understand and tolerate, to have the ability to live hand in a more global society, to have broad interest in life, to have intelligence in relation to one's own interest and talent, as well as to love the environment.

Based on the developmental age of primary school students, mainly those who are in the first and second grade, the way these students think are holistic. Therefore, learning in primary school should be conducted thematically by combining various subjects to make a more meaningful learning. A learning experience that shows relation between conceptual aspects, both within one or more subjects will open chances for the effective and meaningful learning to take place (Triyanto, 2010, p. 5). Thematic cultural art education, in this case, has its own role in giving contribution to achieve the competencies that are aimed by the implementation of the 
2013 curriculum. The education of cultural art that comprises all aspects of life in its implementation, is aiming at helping society and students to strengthen the Indonesian National identity. The sciencebased thematic cultural art education that gives contribution in giving aesthetic experience in cultivating senses, initiatives, and artwork is a form of education that is able to help us in emerging all potentials had by children. It comprises the competence of attitude, knowledge, and skill. Art and science are close and have bounded relation since both are related to the process of discovery as a result of experimenting activities. According to Tolley in Winataputra (2010) explains that the differences between these two subjects lie on their role in explaining the science itself. Science teaches students to critically solve questions regarding to the work of the universe, on the other hand, art teaches them to use universe to be interpreted and recreated. Similarly, the relationship between an artist and a mathematician lies in the construction of thinking. In music, for example, synopsis and improvisation are developed. Creating melody is not only by distinguishing the timbre, but also by adding rhythm and harmony in order to make the song "alive and beautiful". In line with the phenomenon happen in music, in arithmetic, formula, characteristic, and validation is discovered. The three components are becoming a lively one when the three are related and interconnected.

In addition, in fine art, painting promotes sources of material that is rich for the teaching and learning of mathematics. Art can be used in presenting the concept of geometry, including the unlimited ideas. With dance, a dancer can move to make parallel lines, circles, and symmetric patterns either in groups and individually. From the dancer's body shape, anatomy and physics can be learned, for example, when teachers ask students to move and ask them which muscles are working and which one produces enormous energy. By moving, students are introduced to the substance of a dance that is the presence of space, time, and energy. With music, a teacher can explore fraction, musical note, or sound ration. Cultural based learning is a learning environment creation strategy by integrating culture during the process of learning. Culture as a fundamental part of education, expression, and communication of a certain ideas and science development (Winataputra, 2011, p. 4.12).

In standard of competence of graduates in primary school curriculum, it is mentioned that students have to be able to have attitudes that reflect the attitude of believers, noble, confident, and responsible in interacting effectively with the social and natural environment around the students' school or living place. Similarly, in the standard of the process, there is an aspect of soft skill and hard skill improvement and balance comprise the aspect of attitude, skill, and knowledge competence. The standard of the process requires learning in primary school to be conducted by using thematic scientific approach. The education of character has, then become the choice of government to restore the dignity of a nation that is considered to be ruined at the present time. The character education has purposed to shape students in four aspects of management that are the management of thought, the management of feeling, the management of emotion, and in sports. In mass culture that is contented with local wisdom, character education is present.

One of local wisdom that might be implemented as one of learning material in 2013 curriculum is local dance, music, fine art, and drama. Especially in local dance, music, and fine art, physical skill is not the only aspect that is involved in the process of making the art, however, there are implicit symbols and moral values which can be used as role models for society and children in particular. Among aspects that can be emulated are togetherness, respect, team collaboration, persistence, creativity, etc. This competence is expected to be the outcome of 2013 curriculum implementation. In fact, children rarely know about traditional art anymore, although the art 
contains materials, cognitive, and affective activities for children.

The scope of competence that needs to be achieved in cultural art learning in primary school comprises: fine art, music, dance, and craft. Time allocation given to these skills are limited that is 2 hours/ weeks. It results in non-optimal art learning since teacher will only have opportunity to discuss the outer scope of art. In other words, cultural art learning in primary school has not been enough in discussing the main substance of art. Actually, the main substance of art lies in the learning of art's role in society where it may transmit the value and ideas of culture up to the point that it may build cultural identity and emerge the children's creativity.

At the present time, cultural art education has not received much attention, both in its teaching and learning aspect, media, learning materials, or the evaluation process. This condition results in the absence of references that can be used by teachers in teaching cultural art as well as the limited ability of teachers to be able to cultivate the potential of culture and school to support the learning. This is in contrast with the actual phenomenon in society in which every region has their various potentials of culture and arts that can be used as learning media, including traditional games (Handayaningrum, 2007). Primary school teachers as a homeroom teacher positively need a supplement of thematic cultural art learning materials that are in line with the demand of the 2013 teaching curriculum. This is also supported by the fact that there has not many teacher and student books that can help a homeroom teacher in teaching cultural art material.

This study is aimed at discussing the development of learning material of science-based thematic cultural art for primary school under 2013 curriculum. Further, in this study, the learning material produced is the form of a prototype that will need to be tested and validated. The further aim of this study is to inspire teachers to develop learning material that may explore the art and culture resulted and formed by Indo- nesian culture cultivated in our children's environment.

\section{METHOD}

Collaborative developmental research by Borg and Gall (1989) and Puslitjaknov (2008) was implemented in this study. There were five steps in producing the product; 1) Product analysis of research and initial data collection, 2) Initial product development, 3) expert validation and revision, 4) small scale trials and product revision, and 5) mass scale trials and final product.

The first year research comprised observation towards primary school learning in Surabaya that has implemented the 2013 curriculum. The need of learning material was analyzed by focusing on the cultural art learning. After the analysis, results were related to the science learning material, specifically mathematics and sciences, that were in accordance with the chosen theme. Steps were continued with the development of a prototype in the form of teacher and student books. In the second year of research, prototype and product that had been developed are tried out by the learning material experts, material experts, as well as users comprised of both teachers and students. Finally, was the step of revision and recording to the sample of science-based thematic cultural art learning material.

\section{RESULT AND DISCUSSION}

Product resulted from this research is prototype of both teacher and student's science-based thematic cultural art book. The theme of the student book is Kegemaranku or my hobby with sub themes (1) My hobby is playing music, (2) My hobby is drawing, (3) My hobby is dancing, (4) My hobby is playing drama. Each sub theme consists of learnings which combine cultural art with mathematics, sciences, Bahasa Indonesia, and local language. The teacher's book itself consists of guidelines of conducting science-based thematic cul- 
tural art subject. The following is the discussion related to primary schools' scientific-based thematic cultural art subject in the 2013 curriculum.

\section{Thematic Learning}

Thematic learning is the use of themes in interrelating several subjects in teaching in order to give meaningful experience to students. The theme itself is one's key idea that becomes the main discussion (Muslich, 2006). For example, if the theme of the material is Hidup Rukun (Living Hand in Hand), therefore, all other subjects (religion, civics, arts, mathematics) that will be combined should be under the heading Leaving hand in hand as well, and so does with other themes.

In addition, students of first, second, and third grade are below the range of early age. Generally, in this phase of development, they see objects in a whole or holistic way. They also able to understand a simple concept. Learning material relates closely to concrete objects and direct experiences.

Primary school students, or students between 7-11 years old, are at the stage of concrete operation (Piaget as stated by Tridjata, 2005, p. 9.9). During these ages, children start to show characters with the following characteristics: 1) Concrete which implies that the process of learning moves from concrete things, things that can be seen, heard, smelled, touched, and twisted, by emphasizing on the use of the environment as the learning sources. Utilization of environment will result in the most meaningful and valuable process and learning results for students are faced with real and natural condition which validity can be accounted for; 2) Integrative means that primary schooler sees something as a whole object. They have not been able to sort concept from various disciplines; 3) Hierarchy means that primary schooler develops gradually, started from simple things to more complex one. Thus, logical order as well as interrelated materials and scopes are necessary here. Therefore, it seems suitable to give thematic learning to the first, second, and third grade students of primary school.

\section{Science-Based Cultural Art}

Science-based cultural art refers to the cultural art learning as the main medium to introduce local culture products through music, dance, drawing, and drama by integrating sciences, mathematics, Bahasa Indonesia, and local languages. However, since science has not been introduced in the first grade, therefore, science in this learning material is not discussed in deep. Art products in the form of dance, music, drawing, and drama, will help children to understand the basic concept of mathematics about two-dimensional figures, geometry, comparing or estimating longer-shorter, smaller-bigger, or moreless. Besides, through artworks, sources of sound from various musical instrument form wood, animal's skin, metal, bamboo, etc. are introduced. From drawings, students are introduced to animals belong to carnivore and herbivore. Further, examples of mask worn in Javanese traditional puppet will be also enriched students' knowledge about the art of carving. In addition to this is also patterned of batik, Javanese traditional pattern of cloth, that can be also introduced to students from early childhood.

Art is considerably important in every aspect of one's life. The introduction of mathematics and sciences will be more meaningful one it places beside the Indonesian cultural products that are enormous in amount. Since the beginning of childhood, our children will be proud of our own cultures and rich with knowledge of our own cultures, that will result in the strength of children's national identity.

\section{Cultural Art Learning in 2013 Curriculum for Primary School Students Grade 1 and 2}

Curriculum is a series of macro-learning plan. Its role is to be the guide to develop a syllabus and lesson plan that is composed by a curriculum development team and teachers. 2013 Curriculum for cultural art subject relates closely to the curriculum 
emphasizing to the development of spiritual attitude (basic competence one), socio emotional (basic competence two), knowledge (basic competence three) as the basis of skill development (basic competence four). The deepness concept of attitude, knowledge, and skill itself is different to the competence of affective, cognitive, and psychomotor.

The competence of attitude is interpreted as the ability to act based on the knowledge that is manifested in knowledgeable attitude and is not just using feelings to act. Example for this statement is the thought which explains that if a friend is ill, one is supposed to look after the friend or give a help instead of only deliver an empathy. In the implementation of appreciating the arts, one is not only supposed to admire the works, but more to examine the art deeply, criticize it, deeply understand the concept and making process, discover new things, as well as develop and present one's own work to one's teacher or friend. In addition to this is to show the feeling of grateful to God who gives the blessing in a form of talent to him.

The competence of knowledge can be interpreted as the ability to think that is grounded by skills. The ability to think that needs to be taught have to reach the stage where children knows and understands various materials, techniques, and creation process of a certain artwork. Children also need to be able to describe how art is able to present. In the end, children will be able to judge and respect an artwork. The concepts of art will be understood and embedded by children after they experience the art, feel it, and do it.

The competence of skill is interpreted as the ability to create with adequate knowledge and appreciation. In other words, it is a skill to be noble, perseverance, tenacity as well as cooperation in presenting a performance.

According to Ministry of Education and Arts number 65 in 2013 about the standard of process. The principle of learning is:

Attitude: is obtained through artistic ac- tivities (accepting, doing, appreciating, practicing). Knowledge: is obtained through the activity of remembering, understanding, applying, analyzing, evaluating. Skills: is obtained from the activity of: observing, asking, trying, reasoning, presenting, creating. Approach: scientific, integrated across subjects, discovery/ inquiry-based, supportive to contextual creativity and is suggested to problem solving.

In Ministry of Education and Art Regulation number 58 about cultural art subject, it is defined that all activities about recognizing aesthetic, artistic, and creative works are rooted from norms, values, attitudes, and art products of a nation. Further, conceptually, cultural art education is: 1) multilingual, developing the ability of learners to express themselves creatively by utilizing various media of fine art language, word language, sound language, motion or movement language, character language, or the combination between them; 2) multidimensional, the development of various competence of students about the conception of arts; 3) multicultural, developing students' awareness and ability in appreciating nation and other countries' culture; 4) multi intelligence, shaping harmonious personality and psychology including intrapersonal, interpersonal, visual-spatial, verbal-linguistic, musical, mathematic-logic, physical- kinesthetic intelligence, etc.

The general purpose of cultural art is to develop aesthetic and artistic sensibility, critical thinking, as well as appreciative and creative attitude inside the student's self comprehensively. Whereas, the specific purpose of the subject is to: 1) developing tolerance attitude, 2) creating civilization democracy, 3) emerging the need of the students to live harmoniously in a plural society, 4) developing the sensitivity of feeling and skill, 5) implementing technology and creativity, 6) producing product in a form of art performance and exhibition.

Art and culture are terms referring to a subject in primary and secondary school 
level. The term itself has broad and many interpretations. Art has various branches comprising fine art, dance, music, and drama. If all materials from all branches are supposed to be taught in primary and secondary school, surely, the time allotment will be not sufficient. If the knowledge of culture is added, it will be even more complex.

Koentjaraningrat (1979, p. 186) crystallized many definitions of art into an understanding that culture is the manifestation of complex ideas, values, norms, rules, etc. The second manifestation is complex patterned activities and actions of mankind in undergoing live in a society. The third manifestation is mankind artwork, like variety of equipment supporting life up to all valuable and artistic creations.

From previous description, it is obvious that culture is abstract, complex, and broad. In relation to this, culture in primary school cultural art education is then adjusted to the stages of child development. For primary school students grade 1 and 2 , culture can be related to human civilization, such as: manners, ethics, morals, and other related matters.

\section{Steps in Science-Based Thematic Cultur- al Art Learning \\ The Mapping of Competency}

In teaching a thematic subject, a primary school teacher has to have a careful plan. Steps that need to do is firstly to make a mapping of basic competencies of every subject that will be combined. Basic competence is the competence of each subject for each class derived from core or main competence consists of attitudes, skills, and knowledge that must be mastered by learners. The competence is developed by observing the characteristics of students, their basic ability, as well as characteristic of the subject itself. The basic competence of primary school students comprises religion and character, Pancasila and citizenship education, Bahasa Indonesia, Mathematics, Sciences, Social Sciences, Cultural Art and Craft, and Physical Education (Ministry of Education and Art, 2013, p. 8).
Subjects as the source of the content to competencies is open. It is not always organized according to its discipline. It is only oriented to the philosophy of essentialism and perennials. For example, the theme discussed is Kegemaranku or My Hobby with the sub theme is Kegemaranku Bermain Musik or My Hobby is Playing Music. The following is the possible mapping of basic competence from combined subject. The indicators are explained after that.

Subjects belong to a content of an organization that is developed from various disciplines and non-disciplines according to social reconstruction philosophy, progressivism, and humanism. Since the philosophy adopted in the curriculum is eclectic, as it is described in the foundation of philosophy, thus, name and content of the subject of curriculum that will be developed do not need to be bounded to an essential philosophy (the education emphasizes itself in the formation of intellectual and logic) and perennials (an ideal foretime culture).

\section{Scientific Approach}

In achieving its purpose, scientific approach is employed in the 2013 curriculum. It comprises the stages of observing, questioning, exploring, and presenting. Fact-based learning material can be explained with logic or certain rationale; it is not limited to imagination, legend, or fairy tale. Further, scientific approach is supposed to encourage and inspire students to think critically, analytically, and appropriately in identifying, understanding, solving, and implementing the learning material.

Scientific paradigm is not entirely suitable to art education that employs imagination and contemplation in emerging and understanding art works. However, since the approach has become government policy, thus, science-based cultural art learning also needs to implement the scientific approach.

The implementation of science-based cultural art learning is written in students' book by employing the theme Kegemaran- 


\section{BASIC COMPETENCE MAPING OF KI 1 AND KI 2 \\ (Basic Competence 1 and Basic Competence 2)}

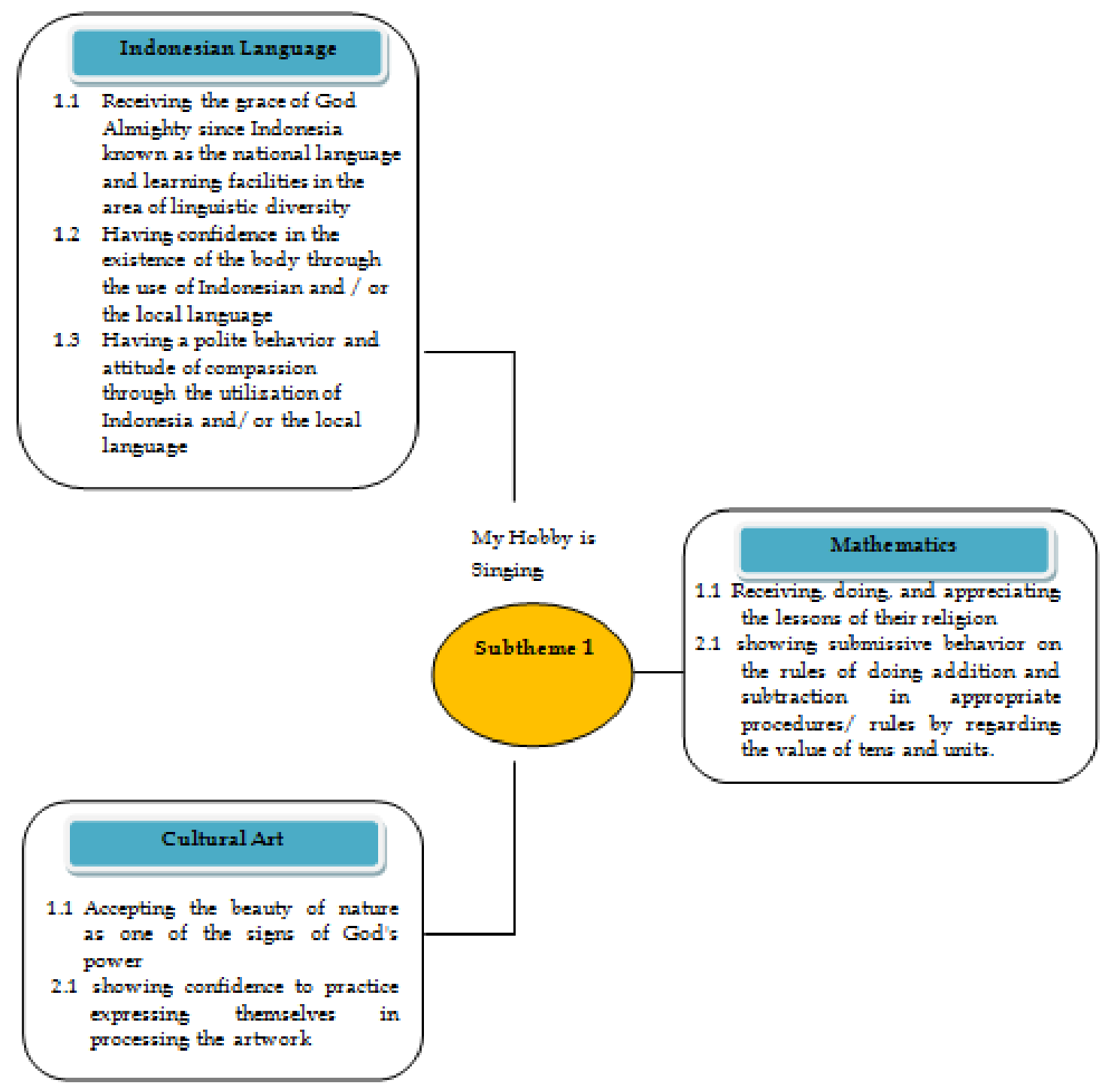

Figure 1. Mapping of Basic Competence

$k u$ or My Hobby, with sub themes (1) My Hobby is Playing Music, (2) My Hobby is drawing, (3) My Hobby is Dancing, (4) My Hobby is Playing Drama. Each such theme is comprised of learning that combines arts with other subjects, such as mathematics, sciences, Bahasa Indonesia, and local languages.

The following is one example of lesson plan implemented in science-based cultural art learning students' book under the sub theme My Hobby is Playing Music.

\section{Opening}

Learning begins with activities outside the classroom where students are standing in line, marching, while singing local songs. In the book, the songs sung are entitled Yo Konco Podo Baris or Let Us Marching and Bel Wis Muni or The Bell has Rung. The songs contain messages about standing up neatly before coming to the class, listening to the teacher afterwards, and be prepared to gain knowledge.

Local language has been introduced since early age at school in order to get the students to be familiar with their own lo- 


\section{BASIC COMPETENCE MAPPING OF KI 3 AND KI 4 (Basic Competence 3 and Basic Competence 4)}

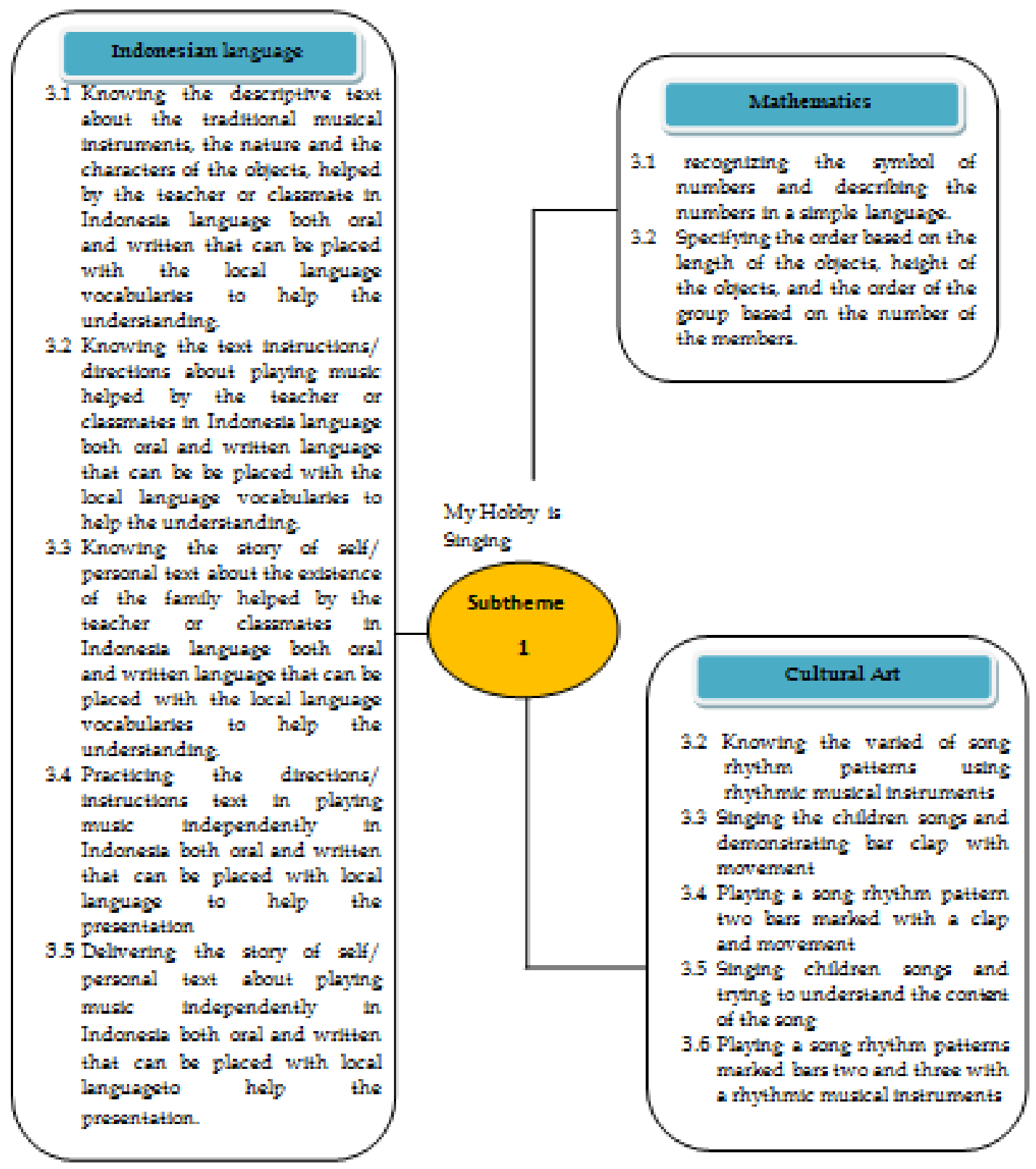

Figure 2. Mapping of Basic Competence

cal language and as a medium to preserve the local language since language will not be forgotten only if it is continuously used by the users. The activity is then continued by praying together before studying. This is in line with the first basic competence which is to remember God. After that, students greet the teacher and friends by singing a song entitled Selamat Pagi or Good Morning as the implementation of second basic competence that is social skill. The song is contained with lesson about being good to God, teachers, friends, as well as to be neat, to be disciplined, etc. This initial song is regularly sung as to form a good habituation within children.

\section{Main Activity}

The first stage in main activity is the stage of observing by identifying a variety of musical instruments in Indonesia, from the Banyuwangi traditional musical 


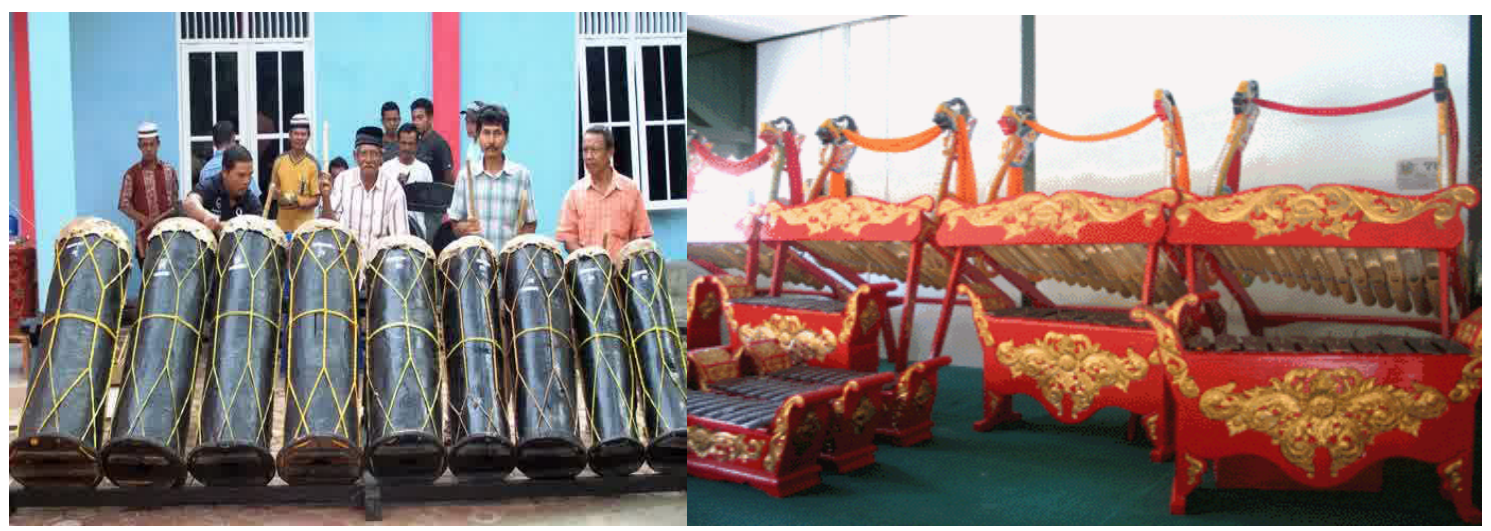

Figure 3. Picture of Kolintang and Gondang Sembilan

instrument up to Balinese traditional musical instrument, Javanese traditional musical instrument, angklung, tambourine, kolintang, and Gondang Sembilan.

In an introduction to Indonesian traditional musical instruments, students are asked to read all the instrument names. This is considered to be important to give appreciation to students about music in Indonesia as well as to teach students to not to be verbalistic. In this part, Bahasa Indonesia subject with the basic competence reading aloud is achieved. Here, the teacher is also expected to give chances to the students to ask about the musical instruments, dealing with its shape, material, techniques to play, origin, etc. Indirectly, students will recognize and be able to identify various shapes of things, for example, round, tube, square; knowledge about the materials, such as: leather, wood, or iron; at the same time as they know and learn about the instruments. The next stage of exploration is by inviting students to understand the shapes of instruments closely and to understand geometry through pictures of the instrument.

Saron, gendang suling, kinds of Javanese traditional musical instrument, tifa, Papua traditional musical instrument, and tambourine are taught to students. They can be asked to match the pictures to how people play the instruments. Still in the stage of exploration, students are invited to play the music that is known as the stage of expression and creation. Playing the music is started by using the internal instrument of one's body that is clapping hands and producing voices.

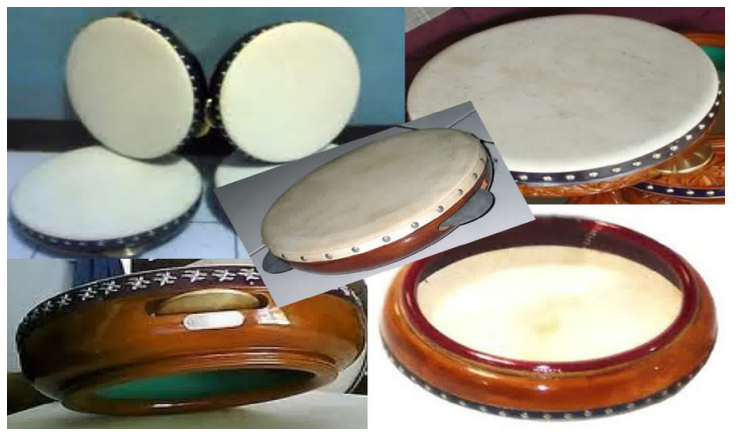

Figure 4. Picture of Tambourine

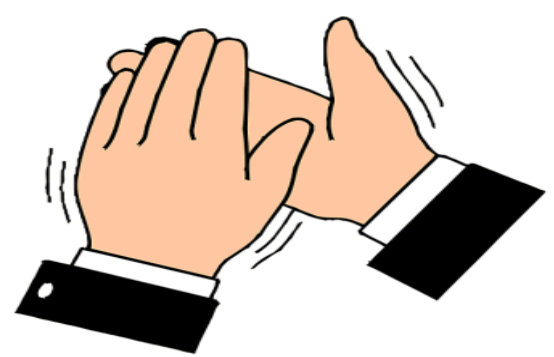

Figure 5. Clapping hands

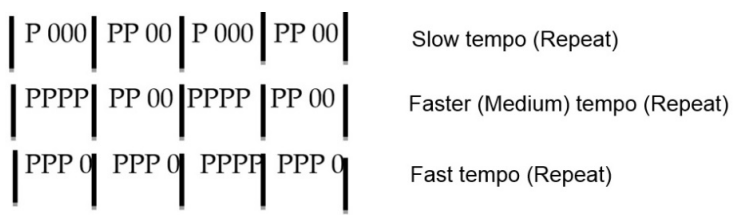

Notes: Clap $=i$ symbolized by $p ; 0=$ stop

Figure 6. Clapping Notation

In the student book version of the learning material, the notation of clapping hands is provided so that both teachers and students can do it by themselves. If it is possible, teachers can provide the actual musical instruments that exist around 
the students' environment. By providing the instruments, students are invited to play the instruments. Besides, students are also introduced to western musical instruments, such as, piano, guitar, violin, drum, and trumpet. This will broaden the knowledge of students about variety of western instruments. Students are also introduced to western solmization notation, do, re, $\mathrm{mi}$, fa, so, la, si, do. In addition to this, in the stage of exploration, students are also asked to compare long-short or big-small a certain musical instrument provided by the teacher. They can also be asked about the addition or subtraction using pictures of musical instruments.

Learning for first grade is suggested to optimize the environment around the children living environment, therefore, in the context of thematic learning, students are invited to use several things around them to produce sound, such as, bottle, gallon, bucket, plate, or spoon. By using the provided notation and under the teacher's instruction, a beautiful rhythm of music will be produced. The next is by inviting students to give music accompaniment to the local songs that are sung together. Thus, in the end of the lesson, in the stage of presentation, students are presenting rhythmical music and enjoyable local songs. The pattern of sub theme playing music with scientific stages can be also implemented to other sub themes, like drawing, dancing, and playing drama. Final$l y$, in the end of the lesson, teachers can do the evaluation based on aspects that have been prepared before, comprising attitude, skill, as well as knowledge.

\section{CONCLUSION}

Science-based thematic cultural art learning can be implemented to introduce cultural art and to learn other subjects in primary school. Through cultural art, the content of mathematics, sciences, Bahasa Indonesia, and local languages can be learned by students happily to improve the quality of learning in primary school, specifically for grade 1 and 2 . Learning can be more pleasant and meaningful. From an early age, children will recognize cultures and the artworks, so that, they will feel proud of their own culture and nation in the future.

\section{REFERENCES}

Handayaningrum, W. (2007a). Pengembangan Pembelajaran Ekspresi Estetika di SD. Research Report. Jakarta: Departemen Pendidikan Nasional. Badan Penelitian dan Pengembangan Pendidikan Pusat Penelitian Kebijakan.

Handayaningrum, W. (2007b). Pengembangan Model Pembelajaran Seni Tari untuk Mengingkatkan Kreativitas Anak TK. Research Report. Surabaya: Lemlit Unesa

Hajar, P. (2011). Pendidikan Seni di SD. Jakarta: Universitas Terbuka

Koentjaraningrat. (1979). Sejarah Teori Antropologi I. Jakarta: UI Press

Muslich, M. (2006). Pembelajaran Berbasis Kompetensi dan Kontekstual,Panduan bagi Guru, Kepala Sekolah dan Pengawas, (Model Tematik Kelas Awal). Jurnal Pendidikan UM, 12 (2), 22-45.

Peraturan Menteri Pendidikan dan Kebudayaan Republik Indonesia tahun 2013

Tim Penyusun. (2006). Panduan Lengkap KTSP. Yogyakarta: Pustaka Yustisia.

Trianto. (2010). Model Pembelajaran Terpadu. Jakarta: Bumi Aksara

Tridajata, C. (2005). Pendidikan Seni di SD. Jakarta: Universitas Terbuka

Winataputra, U. S. (2010). Pembaharuan dalam Pembelajaran di SD, Jakarta: Universitas Terbuka

Yumiati \& Uen Rahayu. (2006). Pembelajaran dengan dan Melalui Budaya dalam Mata Pelajaran Matematika dan IPA di sekolah. 